I6 a 18 de outubro de 2019 - Campinas | Brasil

\title{
Necessidade e Possibilidade na Ética de Espinosa
}

\section{Cleyton Costa Aguiar*, Márcio Augusto Damin Custódio.}

\section{Resumo}

Uma das principais controvérsias que dividem os intérpretes de Espinosa refere-se à abrangência da necessidade em seu sistema. Embora todos concordem que acarrete em determinismo, o debate surge quando se trata de estabelecer se os eventos futuros também são necessariamente determinados. Pretende-se aqui a conciliação de duas perspectivas aparentemente incompatíveis, com base nos diferentes sentidos em que opera a necessidade na Ética de Espinosa.

Palavras-chave: Determinismo, Possibilidade, Contingência.

\section{Introdução}

Há duas interpretações distintas sobre o necessitarismo de Espinosa. Don Garrett (1991) defende que se trata de um necessitarismo estrito, em que todos os eventos são metafisicamente necessários e não poderiam ser diferentes. Enquanto Curley e Walski (1999) defendem um necessitarismo moderado, em que ainda que os eventos presentes sejam necessários, há uma pluralidade de mundos futuros possíveis. Estas interpretações são tomadas como incompatíveis. Defende-se aqui que ambas desconsideram o movimento empregado na Ética de Espinosa, o qual permite diferentes maneiras de se conceber a necessidade.

\section{Resultados e Discussão}

A Parte I da Ética é reconhecidamente onde Espinosa apresenta sua Metafísica. Ali o autor desenvolve a proposição que será a mais recorrida ao se interpretar seu necessitarismo: "As coisas não puderam ter sido produzidas por Deus de nenhuma outra maneira e em nenhuma outra ordem do que aquelas em que foram produzidas" (EIPr33).

As distintas interpretações sobre o necessitarismo de Espinosa batalham na articulação de trechos que corroborem suas teses. Entretanto, não levam em conta que Espinosa realiza na Ética uma dupla consideração sobre os conceitos de possibilidade (possibile) e contingência (contingens), uma quando trata De Deus, e, outra, quando trata Da Servidão Humana. Levada em conta esta diferença abrem-se distintas interpretações sobre a necessidade em Espinosa, que passa a operar de maneira estrita ao se tratar da substância, mas, moderada quando em referência às suas modificações, neste último conjunto se encontram os seres humanos.

Espinosa não estabelece distinção entre o que é possível e contingente na Parte I da Ética. Ao definir estes conceitos na Parte IV apresenta entre eles uma diferença, salientando que no momento anterior não a realizou por não se tratar de uma distinção apurada. $O$ diferencial que provoca a alteração é a ignorância sobre as causas que produzem as coisas, notadamente, aspecto ausente no que tange à substância, a Deus, por isso, não se encontra na primeira parte, mas, presente nos seres humanos.

Os intérpretes em questão não dão relevância ao trajeto que a proposição sobre necessidade, talvez a mais relevante, realiza ao longo da Ética. Assim, desconsideram a alteração nos sentidos de possibilidade e contingência. Este percurso pode ser ilustrado pelo diagrama a seguir, no qual se nota a presença da Proposição 33 na quarta definição da Parte IV:
Figura 1. O Percurso da Prop. 33 da Ética I

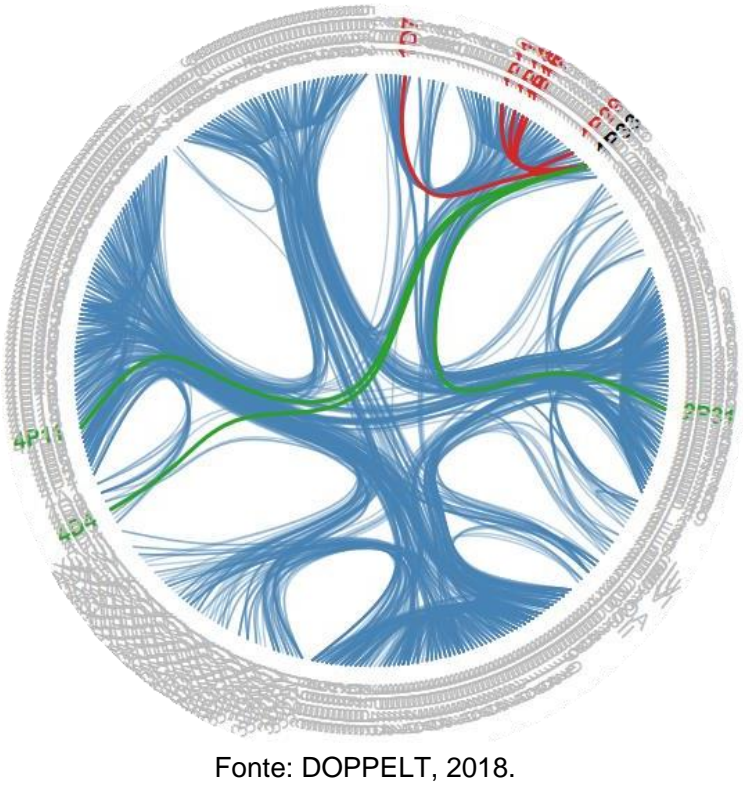

Conclusões

Com isso, a interpretação de Don Garrett de um necessitarismo estrito, em que todos os eventos são metafisicamente necessários e não poderiam ser diferentes é coerente, pois no que tange à substância nem o possível nem o contingente são considerados. Porém, devido à ignorância das causas a mente humana é capaz de conceber uma pluralidade de mundos possíveis, tornando simultaneamente verdadeiras ambas as interpretações que antes pareceram discordantes. Resta ainda discutir se a possibilidade é algo além da ignorância.

\section{Agradecimentos}

Meus agradecimentos ao meu orientador, Prof. Dr. Márcio Augusto Damin Custódio; ao PhD. Torin Doppelt por autorizar o uso das imagens de seu trabalho; ao Grupo de Estudos da Ética de Espinosa (GEÉEsp) e ao Programa Institucional de Bolsas de Iniciação Científica, da Próreitoria de Pesquisa da UNICAMP.

${ }^{1}$ CURLEY \& WALSKI, G. (1999). Spinoza's Necessitarianism Reconsidered; in Gennaro, R.J e Huenemann, C. (eds.), New Essays on the Rationalists, Oxford University Press, New York.

${ }^{2}$ DOPPELT, Torin. (2018). Spinoza's Ethic 2.0. Disponível em: https://ethics.spinozism.org/hierarchical.php. Acessado em 14 de jun. de 2019. ${ }^{3}$ GARRETT, D. (1991). Spinoza's Necessitarianism; in Yirmiahu Yovel (ed.), God and Nature in Spinoza's Metaphysics, Leiden: Brill.

${ }^{4}$ GEBHARDT. (Ed.). (1972). Spinoza opera. v. 1-4. Heidelberg: Carl Winters. 